\title{
PUBLIC URBAN TRANSPORT SERVICES IN THE CONTEXT OF THE METROPOLITAN UNION IN THE SILESIAN VOIVODSHIP
}

\author{
BARBARA KOS
}

University of Economics in Katowice, POLAND

barbara.kos@ue.katowice.pl

RECEIVED
ACCEPTED
JEL
CLASSIFICATION

KEYWORDS

ABSTRACT
8 August 2017

5 December 2017

H41, L98, R48

urban transport, public transport, metropolis, metropolitan union in the Silesian voivodship

Urban public transport is one of the public services of great importance for the functioning of cities. Efficient and accessible public transport ensures residents' mobility, impedes traffic growth and reduces the negative impact of transport on the environment. Progressing urbanization processes are the reason why large cities work together with adjacent municipalities to create supra-local structures and associations in order to provide public transport services. An example of such a solution is the metropolitan union in the Silesian voivodship. The paper presents the basic data characterizing 41 municipalities of the metropolitan union created in the Silesian voivodship, a starting point for further research on integration, transport offer and financing of transport services in the area of the created association.

\section{Introduction}

The aim of social development is to improve the quality of life of the population, measured by a system of indicators for different spheres of life (health system, access to education, development of communal infrastructure and housing, etc.). The public sector, particularly local government, is responsible for the availability and the quality level of public services - the most important services from the communities' point of view. Urbanization is one of 
the most crucial processes of economic, spatial, political and social importance in recent years. The enlargement of urbanized areas and the simultaneous separation of the functions of residential areas, together with the concentration of service and leisure functions, are main factors that increase the mobility of urban dwellers and increase the average distance travelled. Therefore, the transport factor becomes the basic determinant of the development potential of large cities and the quality of life in the city (Tomanek, 2014). In order to ensure the smooth movement of city dwellers within urban areas, it is necessary to use organizational solutions integrating public transport activities beyond existing agreements and unions of municipalities. The aim of this paper is to present issues related to the creation of a metropolitan association in the Silesian Voivodship and the characteristics of the communities involved, focusing especially on the problem of diversity.

\section{Public transport services in uphan areas}

Nowadays services play an important role in socio-economic development. In the literature of the subject, the term "services" is most often understood as all manifestations of economic human activity, which are intangible and characterized by interactivity between the service recipient and the service provider. The fundamental feature distinguishing the services from material goods is their intangibility. Other features of the services - the inseparability of the provision and consumption process, inconsistency (variability), perishability, the impossibility of obtaining ownership - are the result of their intangibility. (Czubała, Jonas, Smoleń, Wiktor, 2006).

Public services (also known as social services, services of general interest) are categories of services of a public nature (non-commercial, free or only with partial fee), aimed at satisfying important social needs. Public services include, among others, health care, education, law enforcement, public transport, postal services, etc. In most countries, ensuring the proper quality level and availability of public services is considered one of the key tasks of the state. Public services are subject to the following requirements: their provision is to be continuous, undisturbed, secure and accessible with attention to their quality. Public authorities are also tasked with defining the standards, measures and techniques for monitoring the provision of public services (Wojciechowski, 2012).

Urban public transport is one of the public services of great importance for the functioning of cities (Starowicz, 2008). Efficient and accessible public transport (Kos, 2017) ensures residents' mobility (Szołtysek, 2011; Kos, Krawczyk, Tomanek, 2018), impedes traffic growth and reduces the negative impact of transport on the environment (Tomanek, 2017). All of this is of particular importance in areas with high population density such as cities. Urban public transport indirectly affects the growth of public activity, including professional activity, which in turn affects the economic development of cities and improvement of the investment climate. Progressing urbanization processes are the reason why large cities work together with adjacent municipalities to create supra-local structures and associations in order to provide public transport services in a wider system than the municipality. At the beginning of the 1990s, in some areas, the municipal law of inter-municipal unions enacted in the Local Government Act was utilized and solutions ensuring the joint organization of public transport services and their integration were implemented (Dz.U., 1990).

An example of such inter-municipal union is the Municipal Transport Union of the Upper Silesian Industrial District in Katowice (pl. Komunikacyjny Związek Komunalny GOP w Katowicach - KZK GOP) operating for more than twenty years in Silesia or the Trans-municipal Passenger Transport Association in Tarnowskie Góry (pl. Międzygminny Związek Komunikacji Pasażerskiej w Tarnowskich Górach - MZKP). 


\section{Legal conditions for metropolitan areas}

The 2003 Planning and Land Use Act defined "metropolitan area" as an area of a big city and a functionally related immediate environment, as defined in the concept of the spatial development of the country (Dz.U., 2003).

The Concept of Spatial Development of the Country 2030 (pl. Koncepcja Przestrzennego Zagospodarowania Kraju 2030 - KPZK 2030) (Rada Ministrów, 2011) is the most important national strategy document on spatial development of the country. KPZK 2030 applies the term metropolitan area consisting of a core and outer zone to entities of various types: urban and rural municipalities forming part of the area, monocentric spatial units (e.g. Poznan) and polycentric (e.g. Tricity, Upper Silesian Agglomeration, bipol Bydgoszcz with Toruń). The necessity of appointing metropolitan centres in the KPZK 2030 results from the provisions of the Land Use Planning Act. Based on the experience of other countries and after analysing ESPON's work, one can consider as metropolises those urban areas (including their functional areas), which are centres of economic governance at least at the national level, which have high economic potential (e.g. transnational investment attractiveness), provide higher-order services and fulfil symbolic functions, are characterized by high external tourism attractiveness, high educational opportunities and innovation (enhanced higher education, presence of research and development units), have the capacity to maintain commercial, scientific, educational and cultural relations with international metropolises and are characterized by high internal and external transport accessibility. The following criteria (data for 2009) were used to designate metropolitan centres (and functional areas around them): population in the metropolitan centre above 300 thousand residents; employment in the market services sector (financial intermediation, real estate and business services) over 40 thousand, the number of students studying in a given city in the academic year 2007/2008 above 60 thousand, cooperation of research institutions in the 5th and 6th EU Framework Programs, the location of the airport serving passenger traffic, the location of four- and five-star hotels, international exhibitions in exhibition venues in the years 2006-2008. The above criteria are fulfilled by: Warsaw, Upper Silesian Agglomeration (the main centre in Katowice), Cracow, Lodz, Tri-city, Poznan, Wroclaw, bipol Bydgoszcz with Torun and Szczecin. In the case of Lublin metropolitan features were indicated, but without the location of the airport serving passenger traffic. However, due to its development significance, e.g. in terms of academic potential (large scientific centre), concentration of economic activity and as a place of contacts with countries located to the east of Poland it was also designated as a metropolitan area (Rada Ministrów, 2011).

In 2007 (8.06.2007), the Silesian Metropolis formally the Metropolitan Association of Upper Silesia (pl. Górnośląski Związek Metropolitalny - GZM) was created as a municipal union composed of 14 cities with county status. The aims of this union are: the general development strategy of the member cities, road infrastructure management, labour market activization, preparation of analysis and reports about the labour market and support for public education (Urz. Woj. Śl., 2007).

According to the Act of 9 October 2015 on Metropolitan Unions (Dz.U., 2015), the basis for a new form of association of territorial local government units was created. The Metropolitan Unions Act, which came into force on January 1,2016 , introduced the possibility of creating metropolitan unions by municipalities and counties of the metropolitan area, defined as "a spatially coherent sphere of influence of a city which is the seat of a voivode or voivodship's council, characterized by strong functional associations, the advancement of urbanization processes and inhabited by at least 500,000 people" (Dz.U., 2015). The Act defined the tasks of the metropolitan union as:

- shaping the spatial order,

- development of the union's area, 
- organization of public transport in the union area,

- cooperation in determining the national and provincial roads within the area,

- promotion of the metropolitan area.

The Act did not predict how many metropolitan relationships should be created in Poland. The Act, due to lack of regulations for implementation, has not been used to create such unions. This led to the relatively swift preparation and adoption of a new Act on March 9, 2017 - on a Metropolitan Union in Silesia (Dz.U., 2017). That means that the scope of such associations was narrowed down to one association in Silesia. However, it was also pointed out that this is a pilot project and does not exclude future expansion of legal regulations for further metropolitan areas in Poland.

\section{The metropolitan union in the Silesian voivodship}

The metropolitan union in the Silesian voivodship is an association of Silesian voivodship's municipalities, characterized by the existence of strong functional links and the advancement of urbanization processes, located in a spatially coherent area with at least 2,000,000 inhabitants.

In the case of the metropolitan union created, a solution was adopted in which, according to Art. 4 sec. 1 of the Act of 9 March 2017, the Council of Ministers may, by regulation: establish a metropolitan union in the Silesian voivodship, determine the name and location of the seat of the authorities, and determine its territory and boundaries by indicating the municipalities belonging to that union. The Ordinance of the Council of Ministers of 26 June 2017 on the establishment of a metropolitan union under the name of "Górnośląsko-Zagłębiowska Metropolia" (Rada Ministrów, 2017) in the Silesian Voivodship states that a metropolitan union under the name of "GórnośląskoZagłębiowska Metropolia" is established in the Silesian Voivodeship with Katowice as the seat of its authorities. The area and boundaries of the metropolitan union "Górnośląsko-Zagłębiowska Metropolia" include (Dz.U., 2017):

- municipalities - cities with county rights: Bytom, Chorzów, Dąbrowa Górnicza, Gliwice, Katowice, Mysłowice, Piekary Śląskie, Ruda Śląska, Siemianowice Śląskie, Sosnowiec, Świętochłowice, Tychy and Zabrze,

- municipalities with town status: Będzin, Bieruń, Czeladź, Imielin, Knurów, Lędziny, Łaziska Górne, Mikołów, Pyskowice, Radzionków, Sławków, Tarnowskie Góry and Wojkowice,

- and municipalities: Bobrowniki, Bojszowy, Chełm Śląski, Gierałtowice, Kobiór, Mierzęcice, Ożarowice, Pilchowice, Psary, Rudziniec, Siewierz, Sośnicowice, Świerklaniec, Wyry and Zbrosławice.

The Regulation came into force on 1 July 2017.

According to the Act on the metropolitan union in the Silesian voivodship, significant changes in the urban public transport system will take place in the next few months in the central part of the Silesian voivodship. During the transformation, there will be a need to solve many problems and thus the opportunity to implement new solutions will appear in the area of financing and integration of public transport. From the point of view of the organization of public transport it is important that the city of Tychy, which until now was outside the scope of KZK GOP (which meant a separate system of public transport) entered into the structure of the new metropolitan union. Also the entry of the town of Tarnowskie Góry to the metropolitan union may change the rules of organization in the northern part of the metropolis. Until now, public transport in Tarnowskie Góry was organized by MZKP Tarnowskie Góry.

KZK GOP, which has dealt with the organization of urban public transport up until now, was formed by 29 municipalities in the central part of the Silesian voivodship, which have all entered the structure of a metropolitan 
union. One of the problems that needs solving is that the municipalities of Orzesze and Ornontowice, and the towns of Oświęcim, Miedźna and Pszczyna which had been served within the agreement of the Municipal Communications Board in Tychy (pl. Miejski Zarząd Komunikacji w Tychach - MZK) have not joined the metropolitan union. Similarly, in the case of the MZKP in the Tarnowskie Góry, the municipalities of Miasteczko Ślaskie, Wielowieś, Krupski Młyn and Toszek remained separate from the structure of the metropolitan union. This will therefore require changing the organizer of transport for the selected lines as well as concluding new agreements to maintain the integrated tariff solutions.

Studying the diversity of municipalities and determining the boundaries of a metropolitan union between municipalities with higher urban density and urban character and rural municipalities, is important in terms of designing future solutions for offering transport services and their funding (Dydkowski, Kos, 2017).

Table 1 presents the basic data characterizing the municipalities forming the metropolitan union of the Silesian Voivodship with the indication of the municipalities previously served by MZK Tychy and MZKP Tarnowskie Góry. It should be noted that in relation to large city data, the number of residents is generally smaller than the number of people staying in the city and using public services. The next columns show the area of a given municipality, the population density allowing for the assessment of the degree of spatial development and urbanization of the city and the amount of exploitation work in the area of particular municipalities. In subsequent columns, the workload was calculated in individual units per capita and per unit area. The total amount of local collective transport allowances per capita and per unit of workload (vehicle-kilometres) was also presented.

Table 1. Basic data characterizing municipalities of a metropolitan union established in the Silesian Voivodeship as at 31.12 .2016 or in 2015

\begin{tabular}{|c|c|c|c|c|c|c|c|c|c|}
\hline No. & Municipality & $\begin{array}{c}\text { Population } \\
\text { in } \\
\text { accordance } \\
\text { to the place } \\
\text { of residence, } \\
\text { as of } \\
31.12 .2016 \\
\text { (inhabitants) }\end{array}$ & $\begin{array}{c}\text { Total } \\
\text { sur-face } \\
\text { area } \\
\left(\mathrm{km}^{2}\right) \\
2016\end{array}$ & $\begin{array}{c}\text { Density of } \\
\text { population } \\
(2016)\end{array}$ & $\begin{array}{l}\text { Transport } \\
\text { operations } \\
\text { within the } \\
\text { area of } \\
\text { municipality } \\
\text { (2015) (vkm) }\end{array}$ & $\begin{array}{l}\text { Saturation } \\
\text { with transport } \\
\text { operations, } \\
\text { number of } \\
\text { vehicle- } \\
\text { kilometres } \\
\text { per } 1 \mathrm{~km}^{2} \text { of } \\
\text { municipality } \\
\text { surface area } \\
(2015)\end{array}$ & $\begin{array}{c}\text { Transport } \\
\text { operations } \\
\text { (in vehicle- } \\
\text { kilometres) } \\
\text { per one } \\
\text { inhabitant } \\
\text { (2015) }\end{array}$ & $\begin{array}{l}\text { Subsidy for } \\
\text { collective } \\
\text { urban transport } \\
\text { (expenditures } \\
\text { for local } \\
\text { collective } \\
\text { transport) per } \\
\text { one inhabitant } \\
\text { (PLN) (2015) }\end{array}$ & $\begin{array}{l}\text { Subsidy for } \\
\text { collective } \\
\text { urban transport } \\
\text { (expenditures } \\
\text { for local } \\
\text { collective } \\
\text { transport) per } \\
\text { one km (PLN) } \\
\text { (2015) }\end{array}$ \\
\hline 1 & 2 & 3 & 4 & 5 & 6 & 7 & 8 & 9 & 10 \\
\hline 1. & Będzin & 57,761 & 37 & 1,546 & $3,911,945$ & 105,728 & 68 & 322 & 4.76 \\
\hline 2. & Bieruń* & 19,575 & 40 & 483 & 46,622 & 1,166 & 2 & 11 & 4.63 \\
\hline 3. & Bobrowniki & 11,905 & 52 & 231 & 817,576 & 15,723 & 69 & 250 & 3.63 \\
\hline 4. & Bojszowy ${ }^{*}$ & 7,630 & 35 & 220 & 220,000 & 6,286 & 29 & 121 & 4.20 \\
\hline 5. & Bytom & 170,059 & 69 & 2449 & $7,223,434$ & 104,687 & 42 & 208 & 4.91 \\
\hline 6. & Chełm Śląski* & 6,144 & 23 & 263 & 231,975 & 10,086 & 38 & 184 & 4.87 \\
\hline 7. & Chorzów & 109,541 & 33 & 3,295 & $4,318,803$ & 130,873 & 39 & 158 & 4.01 \\
\hline 8. & Czeladź & 32,225 & 16 & 1,967 & $1,252,832$ & 78,302 & 39 & 169 & 4.37 \\
\hline 9. & Dąbrowa Górnicza & 122,451 & 189 & 649 & $6,632,730$ & 35,094 & 54 & 269 & 4.98 \\
\hline 10. & Gierałtowice & 11,834 & 38 & 311 & 534,505 & 14,066 & 45 & 183 & 4.03 \\
\hline 11. & Gliwice & 182,969 & 134 & 1,367 & $6,945,095$ & 51,829 & 38 & 129 & 3.40 \\
\hline 12. & Imielin ${ }^{*}$ & 8,888 & 28 & 318 & 125,541 & 4,484 & 14 & 64 & 4.52 \\
\hline 13. & Katowice & 299,012 & 165 & 1,816 & $19,696,603$ & 119,373 & 66 & 303 & 4.62 \\
\hline 14. & Knurów & 38,685 & 34 & 1,139 & 920,348 & 27,069 & 24 & 102 & 4.29 \\
\hline
\end{tabular}




\begin{tabular}{|c|c|c|c|c|c|c|c|c|c|}
\hline 1 & 2 & 3 & 4 & 5 & 6 & 7 & 8 & 9 & 10 \\
\hline 15. & Kobiór ${ }^{*}$ & 4,905 & 48 & 102 & 68,000 & 1,417 & 14 & 59 & 4.24 \\
\hline 16. & Lędziny" & 16,807 & 32 & 531 & 229,003 & 7,156 & 14 & 62 & 4.52 \\
\hline 17. & Łaziska Górne* & 22,418 & 20 & 1,117 & 636,000 & 31,800 & 28 & 120 & 4.21 \\
\hline 18. & Mierzęcice" & 7,632 & 49 & 154 & 458,392 & 9,355 & 60 & 179 & 2.98 \\
\hline 19. & Mikołów & 40,027 & 79 & 505 & $1,901,166$ & 24,065 & 48 & 208 & 4.38 \\
\hline 20. & Mysłowice & 74,711 & 66 & 1,139 & $3,064,135$ & 46,426 & 41 & 176 & 4.31 \\
\hline 21. & Ożarowice" & 5,714 & 46 & 125 & 415,495 & 9,033 & 73 & 215 & 2.05 \\
\hline 22. & Piekary Śl. & 56,126 & 40 & 1,404 & $2,422,643$ & 60,566 & 43 & 114 & 2.65 \\
\hline 23. & Pilchowice & 11,618 & 70 & 166 & 107,773 & 1,540 & 9 & 38 & 4.05 \\
\hline 24. & Psary & 11,939 & 46 & 259 & 695,880 & 15,128 & 59 & 223 & 3.81 \\
\hline 25. & Pyskowice & 18,418 & 31 & 596 & 382,324 & 12,333 & 21 & 65 & 3.12 \\
\hline 26. & Radzionków & 16,965 & 13 & 1,285 & 432,279 & 33,252 & 25 & 78 & 3.05 \\
\hline 27. & Ruda Śląska & 139,412 & 78 & 1,794 & $5,562,055$ & 71,308 & 40 & 129 & 3.25 \\
\hline 28. & Rudziniec & 10,638 & 159 & 67 & 8,136 & 51 & 1 & 3 & 3.98 \\
\hline 29. & Siemianowice Śl. & 68,011 & 25 & 2,667 & $2,474,100$ & 98,964 & 36 & 111 & 3.07 \\
\hline 30. & Siewierz & 12,323 & 114 & 108 & 470,765 & 4,130 & 38 & 151 & 3.93 \\
\hline 31. & Sławków & 7,092 & 37 & 193 & 221,238 & 5,979 & 31 & 122 & 3.93 \\
\hline 32. & Sosnowiec & 206,516 & 91 & 2,268 & $8,780,672$ & 96,491 & 42 & 228 & 5.38 \\
\hline 33. & Sośnicowice & 8,742 & 116 & 75 & 100,637 & 868 & 12 & 45 & 3.88 \\
\hline 34. & Świerklaniec** & 11,888 & 45 & 266 & 664,530 & 14,767 & 56 & 120 & 3.04 \\
\hline 35. & Świętochłowice & 50,750 & 13 & 3,813 & $1,445,906$ & 111,224 & 28 & 156 & 5.51 \\
\hline 36. & Tarnowskie Góry & 61,099 & 84 & 730 & $2,560,143$ & 30,478 & 42 & 128 & 3.05 \\
\hline 37. & Tychy & 128,415 & 82 & 1,570 & $5,574,028$ & 67,976 & 43 & 189 & 4.35 \\
\hline 38. & Wojkowice & 9,078 & 13 & 710 & 554,987 & 42,691 & 61 & 221 & 3.61 \\
\hline 39. & Wyry" & 7,876 & 35 & 227 & 187,000 & 5,343 & 24 & 101 & 4.22 \\
\hline 40. & Zabrze & 175,882 & 80 & 2,188 & $6,857,997$ & 85,725 & 39 & 188 & 4.83 \\
\hline 41. & Zbrosławice" & 15,879 & 148 & 107 & $1,233,699$ & 8,336 & 78 & 234 & 3.01 \\
\hline
\end{tabular}

"Municipalities served by MZK Tychy.

" Municipalities served by MZKP Tarnowskie Góry.

Source: based on GUS (2017), KZK GOP (2017); data obtained from MZKP Tarnowskie Góry; data obtained from MZK Tychy.

On the basis of the data collected, a great diversity between municipalities constituting a metropolitan union in the Silesian Voivodship can be observed, both in terms of population size, population density, transport operations (measured in vehicle-kilometres), as well as in transport operations per capita work and per surface area $\left(\mathrm{km}^{2}\right)$. In individual municipalities, a subsidy for collective transport per capita as well as for one vehicle-kilometre of transport operations, is also very different. There is therefore considerable variation in the municipalities of the established metropolitan union - from the point of view of the features important for the organization of collective public transport. That can be partially explained by different functions performed by each of the municipalities described.

\section{Conclusions}

It can be observed that the approach to the delimitation of metropolitan areas in the legal regulations has changed. On April 4, 2017, the President of the Republic of Poland signed a law of March 9, 2017 for a metropolitan union in the Silesian voivodship, characterized by the existence of strong functional links and the advancement of 
urbanization processes, located in a spatially coherent area with at least 2,000,000 inhabitants. The adoption of that Act is the result of long-standing discussions on the introduction of special solutions for metropolitan areas. According to the Act, the Council of Ministers established a metropolitan union under the name of "GórnoślaskoZagłębiowska Metropolia" in the Silesian voivodship, assigned its name, location for its seat of authorities and determined its territory and boundaries by indicating the municipalities belonging to that union. The tasks related to collective public transport are among the most crucial for the metropolitan union.

Municipalities forming the metropolitan union operate in consistent structures and already carry out or should carry out a uniform communication policy. The fact that the metropolitan union that will be formed will cover all municipalities of the currently functioning KZK GOP is very positive, since it will facilitate further organizational transformations related to the inclusion in the integrated public transport system of municipalities previously served by the MZK Tychy and MZKP Tarnowskie Góry.

\section{References}

Czubała, A., Jonas, A., Smoleń, T., Wiktor J. (2006). Marketing usług. Kraków: Oficyna Ekonomiczna.

Dydkowski, G., Kos, B. (2017). Metropolizacja zarządzania miejskim transportem zbiorowym w województwie śląskim. Studia Ekonomiczne, 336, 9-23.

Dz.U. (1990). Ustawa z dnia 8 marca 1990 r. o samorządzie gminnym. Dz.U. nr 16, poz. 95 z późn. zm.

Dz.U. (2003). Ustawa z dnia 27 marca 2003 r. o planowaniu i zagospodarowaniu przestrzennym. Dz.U. nr 80, poz. 717.

Dz.U. (2015). Ustawa z dnia 9 października 2015 r. o związkach metropolitalnych. Dz.U. poz. 1890.

Dz.U. (2017). Ustawa z dnia 9 marca 2017 r. o związku metropolitalnym w województwie śląskim. Dz.U. poz. 730.

GUS (2017). Główny Urząd Statystyczny. Retrieved from: www.stat.gov.pl (20.05.2017).

Kos, B. (2017). The Significance of Public Urban Transport in the Process of Balancing of Urban Mobility. In: III Georgian-Polish International Scientific-Technical Conference: Transport Bridge Europe-Asia (pp. 108-112). Kutaisi: Conference Materials.

Kos, B., Krawczyk, G., Tomanek, R. (2018). Modelowanie mobilności w miastach. Katowice: Wydawnictwo Uniwersytetu Ekonomicznego w Katowicach.

KZK GOP (2017). Biuletyn Informacji Publicznej Biura KZK GOP. Retrieved from: www.bip.kzkgop.pl (20.05.2017).

Rada Ministrów (2011). Uchwała nr 239 Rady Ministrów z dnia 13 grudnia 2011 r. w sprawie przyjęcia Koncepcji Przestrzennego Zagospodarowania Kraju 2030, Monitor Polski, Dziennik Urzędowy Rzeczpospolitej Polskiej, Warszawa, 27.04.2012, poz. 252.

Rada Ministrów (2017). Rozporządzenie Rady Ministrów z dnia 26 czerwca 2017 r. w sprawie utworzenia w województwie śląskim związku metropolitalnego pod nazwą „Górnośląsko-Zagłębiowska Metropolia” (Dz.U. 2017, poz. 1290).

Starowicz, W. (2008). Jakość usług w miejskim transporcie publicznym. Kraków: Wydawnictwo Politechniki Krakowskiej.

Szołtysek, J. (2011). Kreowanie mobilności mieszkańców miast. Warszawa: Wolters Kluwer.

Tomanek, R. (2017). Low-Carbon Mobility in Metropolitan Areas - Based on the Example of Silesian Metropolis. In: III Georgian-Polish International Scientific-Technical Conference: Transport Bridge Europe-Asia (pp. 201-205). Kutaisi: Conference Materials.

Tomanek, R. (2014). Telematics in the New EU Cohesion Policy on the Example of Integrated Territorial Investments Strategy. Telematics - Support for Transport Communications in Computer and Information Science, 434-440. DOI:10.1007/978-3-662-45317-9_46.

Urz. Woj. Śl. (2007). Dz. Urz. Woj. Śląskiego nr 108 z 28.06.2007r., poz. 2163.

Wojciechowski, E. (2012). Gospodarka samorządu terytorialnego. Warszawa: Difin.

Cite this article aS: Kos, B. (2018). Public Urban Transport Services in the Context of the Metropolitan Union in the Silesian Voivodship. European Journal of Service Management, 1 (25), 133-139. DOI: 10.18276/ejsm.2018.25-16. 